\title{
Romantiske selviscenesættelser
}

\section{Charlotte Smith og Lord Byrons frontispice-portrætter}

14 Spørgsmålet om, hvad digtningens væsen er, er så tæt på at være det samme spørgsmål som, hvad digterens væsen er, at svaret på det ene er en del af løsningen på det andet. ${ }^{1}$

46 En bog uden et portræt af forfatteren er værre end anonym. På en kirkegård kan man kigge på ribben og skinneben som blot så mange stave, uden interesse, men hvis der skulle være et kranie i nærheden, så påkalder det sig resterne med det samme, - således er det med forfatterens hoved foran hans sider. Portrættet gør krav på værket. ${ }^{2}$

Den 15. maj 1797 lykkedes det efter lang tids møje og besvær for Charlotte Smith (1749-1806) at få sit portræt udgivet på frontispicen til andet bind af hendes populære Elegiac Sonnets and Other Poems (se fig. 1). Denne bog var da udkommet i seks udgaver siden 1784, og selvom der for hver udgave blev inkluderet nye digte, behøvede den i syvende udgave noget nyt og interessant for at fastholde og udvide sit publikum. Sammen med fire regulære illustrationer, der supplerede de fire, som var blevet tilføjet sjette udgave i 1792, kunne et frontispice-portræt af digteren gøre bogen attraktiv på ny og, som Smith skriver i et brev, "answer extremely well as to profit". ${ }^{3}$ For Smith, der var eneforsørger af en stor børneflok, var profit altid et centralt motiv for udgivelse. ${ }^{4}$ Det var ikke tilfældet for hendes på mange måder diametrale modsætning, George Gordon, Lord Byron (1788-1824), som det i 1812 lykkedes ikke at få sit portræt på frontispicen til årets store og bedstsælgende mediefænomen, Childe Harold's Pilgrimage.

Brugen eller, som vi skal se i Byrons tilfælde, ikke-brugen af forfatterens portræt som blikfang i markedsføringens (u)hellige navn daterer sig naturligvis længere tilbage end Smith, om end der i sidste halvdel af det attende og første halvdel af det nittende århundrede fremkom et regulært marked for graverede forfatterportrætter, der var blevet eftertragtede samleobjekter - få mere end Byrons..$^{5}$ Lysten til at samle graverede portrætter var blevet stimuleret af Samuel Grangers' Biographical History of England (1769), som inkluderede en lang række portrætter af 
biografisk digtning. I denne optik - som også Byron må læses i - bliver portrættet en del af værket i en kunstnerisk og ekspressiv forstand, der rækker ud over, om end den på problematisk vis er impliceret i, den kommercielle logik. Smith bruger ikke portrættet i en så højt reflekteret og bevidst grad, som vi ser det hos Walt Whitman, der i 1855 udgav Leaves of Grass uden sit navn, men med sit portræt på frontispicen. Men nok til at man kan sige, at det er hos Smith, den proces sættes i gang, som resulterer i, at portrættet bliver et mere intimt integreret aspekt af værket i æstetisk forstand end tidligere, og som muliggjorde den indsigt, Whitman giver udtryk for $i$ en anonym anmeldelse af sin egen bog: "His name is not on the frontispiece but his portrait, half length, is. The contents of the book form a daguerreotype of his inner being, and the title page bears a representation of its physical tabernacle". ${ }^{\text {Io }}$

\section{I}

William Wordsworth var en tidlig beundrer af Smith, som han læste og opsøgte i starten af 1790'erne. I 1833 anerkendte han hendes betydning, da han sagde, at hun var en digter "to whom English verse is under greater obligations than are likely to be either acknowledged or remembered". ${ }^{\text {II }}$ En af de ting, Wordsworth og engelsk digtning skylder Smith, er legitimeringen af dette, at digtningen tager digterens eget liv som sit materiale i en ekspressiv digtning. Således konkluderer Jacqueline Labbe en af de første kritiske monografier om Smith med at sige, at "ved at skrive en Selvets digtning producerer, instruerer og udfører Smith Romantikken". ${ }^{12}$ For den tidligere romantikkritik var Wordsworth ophavsmand til denne æstetiske revolution, der lagde grunden til den moderne digtning. Som Harold Bloom har sagt, var Wordsworth "opfinderen af moderne digtning, og han fandt ikke andre emner end sig selv [he found no subject but himself]"; ${ }^{13}$ med andre ord, Wordsworth "begyndte moderne digtning, det voksende indre selvs digtning". ${ }^{14}$ Denne litteraturhistorie er nu under revision i lyset af genopdagelsen af Smith. I første omgang i forhold til spørgsmålet om originalitet, ${ }^{15} \mathrm{i}$ anden omgang i forhold til den måde det nye stof finder udtryk på. For Bloom og en række andre toneangivende romantikforskere fra anden halvdel af det tyvende århundrede (fx M. H. Abrams og Geoffrey Hartman) var forudsætningen for romantikkens originale og revolutionære fokus på at udtrykke digterens indre opgivelsen af interessen for det ydre, visuelle og materielle. Som Bloom siger et sted, "Romantisk digtnings byrde er absolut frihed, inklusiv friheden fra det kropslige øjes tyranni, og denne frihed stammede tilsyneladende delvist fra den specifikt protestantiske indflydelse, der muliggjorde moderne digtning". ${ }^{16}$ Genlæsningen af Smiths værk nødvendiggør en revision også af denne opfattelse.

I de adskillige og voksende forord samt det udførlige noteapparat til Elegiac Sonnets påpegede Smith sin digtnings forankring i empiriske fakta og insisterede på dens autenticitet ved at sige, at den udelukkende baserede sig på hendes egne erfaringer som melankolsk, sorgfuld og nødlidende kvinde ramt af ulykkelig kærlighed, og som trængt, hårdtarbejdende og eneforsørgende moder. Smith opbyggede et personligt og intimt forhold til sit publikum, som hun indviede i sine private ulyksalige forhold. Denne biografiske forankring af hendes overvejende melankolske og sentimentale digtning var et væsentligt aspekt ved hendes store succes. ${ }^{17}$ I 1787 
skrev Sir William Jones for eksempel og takkede en ven for Smiths bog: "I thank you heartily, my dear Sir, for the tender strains of the unfortunate Charlotte, which have given us pleasure and pain; the sonnets which relate to herself are incomparably the best". ${ }^{18}$ Her peges på det personlige og intimes tiltrækningskraft, hvilket udtrykkes i brugen af Smiths fornavn, "the unfortunate Charlotte". Attraktionen ved og Smiths udnyttelse af det intimt selvbiografiske understreges og opsummeres af brugen af hendes portræt i 1797.

Smith taler første gang om muligheden for at udgive et portræt af sig selv med sine digte i et brev i 1792 (Letters 54). Problemet er blot, som hun skriver i et brev to år senere, at der kun eksisterer ét brugbart portræt, lavet af den berømte portrætmaler Charles Romney i 1792, som indehaveren, Smiths mæcen William Hayley, ikke vil give slip på med henblik på reproduktion og ikke vil lade kopiere i sit hus. I mellemtiden har Smith været ramt af svær sygdom, hvilket, skriver hun, "has so very much changed my appearance that nobody wd know me who had not seen me for two years to be the same person" (Letters 104). Hun har derfor i første omgang afslået Romneys generøse tilbud om kvit og frit at male et nyt portræt i håbet om, at Haley vil lade det eksisterende gravere, men erklærer sig rede til at blive portrætteret ("as I believe it is wronging my children not to do so"), selvom hun beskriver sig selv som "hideous" (Letters 104). Et portræt af hende som hæslig er bedre end intet portræt, selvom et portræt af hende i mere tiltalende udgave naturligvis er at foretrække.

I 1794 forestiller Smith sig, at bogen med illustrationer og portræt kunne udkomme efter tolv måneder. Dette holdt ikke stik, dels pga. sygdom og andet arbejde (hun skrev ca. en roman om året, hvilket var hendes primære indtægtskilde), dels pga. problemet med at fremskaffe portrættet, dels fordi hun selv ville føre opsyn med udfærdigelsen af illustrationerne, hvilket komplicerede processen, og dels fordi det var omkostningsfuldt at få dem lavet og tidskrævende at rejse de midler, som skulle finansiere deres fremstilling. I et brev fra november 1796 til sine udgivere opstiller Smith et budget, der antager, at udgiften til illustrationer beløber sig til mere end halvdelen af de samlede udgifter (Letters 241). Men som hun siger få dage senere, da hendes udgivere har skrevet tilbage, at det vil være endnu dyrere at få graveret hendes illustrationer, end hun forestillede sig, hvis det skal gøre ordentligt: "There are no set of Men to whom I would so willingly pay money if I had it as Artists of merit [...] I had rather gain less [...] than have the last book of the kind I shall ever publish appear shabbily done and in a bad taste" (Letters 243).

Vi ser her, at der er andre ting på spil end de rent økonomiske i fremstillingen af denne bog, som Smith forestillede sig skulle udgøre hendes digteriske eftermæle. Langt hen ad vejen er argumentet om, at det kan betale sig med portræt og illustrationer, et dække for ødelæggende beskyldninger om egoisme og selveksponering. På den ene side ville det klart kunne betale sig at betone bogens visuelle udtryk, men så skulle Smith opgive en stor del af sin kunstneriske integritet og lade udgiverne bestemme det hele med større profit, men også tvivlsom kvalitet som konsekvens. ${ }^{19}$ Smith ville ikke gå på kompromis hverken med illustrationerne eller med sit portræt. Der eksisterede nemlig et andet portræt af hende (lavet af gravøren Thomas Hardy), som kunne have været brugt som erstatning for det svært tilgængelige, men 
ifølge Smith var Hardys portræt "so very unlike that I might as well send a portrait of Mother Shipton to the engraver" (Letters 244). ${ }^{20}$ For en tilpas skruppelløs udgiver ville det ikke være noget problem med et grimt og sjusket portræt, som ikke lignede forfatteren, så længe der var et portræt, ej heller med sjuskede genbrugte illustrationer uden umiddelbar forbindelse til teksten.

Det tog tid at få lavet originale tegninger, og det tog tid at få dem graveret. Endelig tog det tid at få dem ændret, så de tilfredsstillede Smith. I et brev fra marts 1797, hen mod slutningen af processen, skriver hun til sine udgivere med henvisning til en af illustrationerne:

$6 f$ I am charm'd with the landscape part which is the prettiest thing I ever saw in my life, but I think the figure of the Nymph too fat. It takes off all that pensive look which becomes such an ideal being \& looks more like the plump damsel of the Dairy than a Naiad [...] A very little alteration wd do away all these objections, \& I dare say Mr Corbould [kunstneren] wd have the goodness to name to the engraver these little remarks, so as to have them (the changes) made without altering the drawing. (Letters 255)

Smith kommenterer på andre detaljer end de nævnte, og visse af dem ændres (jf. Letters $256 \mathrm{n} 2$ ), men en måned senere skriver hun igen om den alt for buttede nymfe, som hun ønskede var mere tænksom og vemodig ("pensive"), og viser, hvor omstændeligt det hele var, dels pga. den forhåndenværende teknologi, dels pga. hendes perfektionisme og det svære ved præcist at redegøre for hendes intentioner angående illustrationerne:

64 Mr Corbould originally faild in comprehending my idea which perhaps was for want of my expressing myself clearly. But my notion which I meant to give him was that of a River Nymph — The fat girl he first produced was any thing but such an ideal Sylphish representation. She is now a little subdued but still not a river Nymph, not the Naiad of a Stream or any thing like one, but the figure is now simple \& pretty, and the Landscape, tho a little too dark, very much what it ought to be in general, \& upon the whole I shall take the figure for the Phoebe of "the Forest Boy" instead of what I had intended it for- the closing Poem-As it will not badly represent her melancholy Musing —

By the brook where it winds thro' the Copse of Arbeal

But I wish that, if it can be done without much trouble, that a little more of sorrowful, mournful expression may be given to her Countenance \& I will add another which may I beleive be done with a single stroke of the Graver about the mouth or perhaps brows. (Letters 267)

Da Smith ikke kan få en sylfide, som er tilpas vemodig, sorgfuld og melankolsk, rokerer hun rundt på tekst og billede således, at der opnås en bedre overensstemmelse mellem den kornfede pige, hun har fået (se fig. 2), og digtet "The Forest Boy", som oprindeligt ikke var tiltænkt en illustration. I digtet beskrives Phoebe som en sund og harmonisk del af naturen, før hendes forlovede, The Forest Boy, bliver lok- 
ket i krig og omkommer. Dette sender hende i dyb melankoli og bringer hende på vanviddets rand i de vers, som illustrationen knyttes direkte til:

46 By the brook where it winds thro' the wood of Arbeal,

Or amid the deep forest, to moan,

The poor wandering Phoebe will silently steal;

The pain of her bosom no reason can heal. ${ }^{21}$

Illustrationen giver et billede af en naturskønhed under omformning, selvom Smiths sidste kommentar ang. illustrationerne igen var rettet mod at få gjort Phoebe mere melankolsk og sorgfuld og dermed bragt tættere på digtets grundstemning: "except the slight alteration of giving an expression somewhat more melancholy to Phoebe $[\ldots]$ it will be as well to let them remain as they are. If they are not exactly what I wish, it is some satisfaction to know that [they] are infinitely superior both in taste \& execution to most of such plates in the books daily publish'd" (Letters 272).

I brevet fra marts 1797 kommenterer hun også den graverede version af en tegning baseret på Romneys portræt, som det endelig var lykkedes at fremskaffe:

In regard to my picture, I [...] very much doubt whether the faults that I see in the engraving can be alterd. The face is too long; that must remain so, I know. My family \& such friends as I have shewn it to think there is a want of spirit in the eyes. If that can be amended it may, \& I will send up the picture with the book. Under the portrait is to be this motto from Shakespeare which perhaps may be set about immediately:

Oh! grief has changed me since you saw me last

And sorrowing hours with times deforming hand

Have written strange defeatures in my face- (Letters 255-6)

Smiths ansigt siges at være overskrevet af "times deforming hand" og fremstilles som en tekst, der kan læses på samme måde som de tekster, Smith har forfattet. Mottoet fra Shakespeares Comedy of Errors fremstår som udsagt af portrættet, og det etablerer Smith selv som den autentiske kilde til de sorgfulde og melankolske

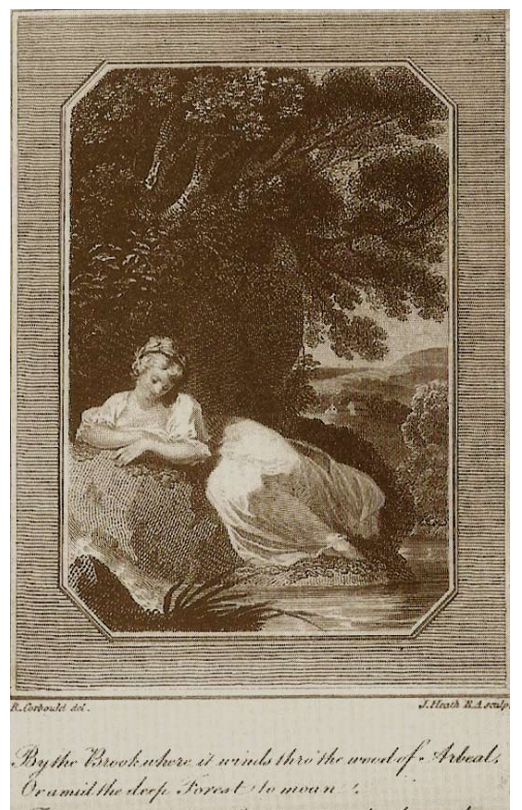

Fig. 2: Illustration til "The Forest Boy",

i Elegiac Sonnets (1797) 
figurer i størstedelen af digtene, eksempelvis Phoebe i "The Forest Boy". ${ }^{22}$ Forbindelsen mellem Phoebe og Smith understreges ikke blot af tilstedeværelsen af deres sorgfulde og vemodige portrætter, men af en faktuel fodnote til "The Forest Boy", hvor Smith påpeger, at hun har del i Phoebes oplevelse af at miste en elsket i krig, idet en af hendes sønner mistede et ben i krigen mod Frankrig i 1793. ${ }^{23}$

Selvom frontispice-portrættet siges at fremvise resultatet af sorgens deformerende skriftlige arbejde, og mottoet siger, hun engang var mere tiltalende, så ville Smith antageligvis se ganske anderledes ud, hvis vi var blevet tilbudt et troværdigt portræt af hende i udgivelsesøjeblikket 15. maj 1797. Som nævnt beskriver hun sig selv som "hideous" i 1794 sammenlignet med portrættet, mens hun to år senere siger, at hun er "so very much alter'd that it would be mortifying to me to have a likeness of me taken" (Letters 236). Portrættet ligner 'hende', som hun ønsker at se ud som en stadig attraktiv person, snarere end som hun faktisk så ud i 1797, da bogen og portrættet udkom. Et billede af hende fra 1797 ville vise hende som alt for deformeret af sorgens og tidens arbejde. Hun skulle se melankolsk ud, og gerne mere end den buttede Phoebe, men helst uden at skræmme bogens læsere og købere væk, som det fx ses af hendes bekymring omkring det lidt lange ansigt og den manglende gejst ("spirit") i øjnene.

Idealiseringen og skønmaleriet i forbindelse med fremstillingen af det graverede portræt viser, at det ikke er den 'rigtige' Charlotte Smith, vi har med at gøre, men en til lejligheden konstrueret og iscenesat udgave af hendes selv. At portrættets tale ikke er Smiths egen, men taget fra et skuespil, understreger dette teatralske element; og at talen stammer fra en komedie om to sæt tvillinger, der hele tiden bliver forvekslet med hinanden, er måske en påmindelse om ikke at læse hende som helt så gravalvorlig, tragisk og melankolsk, som hun lægger op til. 'Smith' som forfatter til Elegiac Sonnets er en rolle, der spilles i det, D. F. McKenzie i anden forbindelse kalder "the hand-held theatre of the book", ${ }^{24}$ hvor forfatteren så at sige skaber sig selv som kunstværk foran sit publikum. For så vidt den romantiske digter tilstræbte at realisere sig selv gennem kunstnerisk aktivitet, som bl.a. Charles Taylor påpeger i Sources of the Self, er Smiths brug af sit portræt i, hvad hun troede skulle blive hendes sidste digtbog, hendes måde at opsummere sit væsentligste digteriske livsværk under et samlende tegn på, hvor det begynder og slutter. ${ }^{25}$

Som Wordsworth forudså i 1833, har eftertiden behandlet Smith med glemsel. En af de ting, som i sampil med hendes køn utvivlsomt har været medvirkende årsag til dette, er det, som netop aktualiserer hende i dag: Hendes udprægede bevidsthed omkring betydningen af bogens materialitet og hendes integration og realisering af denne bevidsthed i et gennemgående æstetisk projekt, der havde iscenesættelsen af hende selv som omdrejningspunkt. Hun viser, at de yderst selvbevidste romantiske digtere i England brugte bogvæsenets visuelle virkemidler i det æstetiske arbejde, hvilket både romantikkritikken og den nye tekstuelle kritik har været langsomme til at anerkende. På den ene side har man ikke haft den teoretiske ramme, som D. F. McKenzie, Jerome McGann, Gérard Genette og andre har etableret over de seneste ti-tyve år, og som har gjort, at man nu kan finde dette værdifuldt. Tværtimod, for på den anden side har man haft en snævert defineret 'romantisk' opfattelse af, hvad den sande digter er og gør, som ekskluderer Smiths teatralske og iøjnefal- 
dende samt delvist kommercielt motiverede selviscenesættelser. Denne opfattelse udtrykkes tydeligt hos Mario Praz, når han siger, at "Romantikeren ophøjer den kunstner, som ikke giver materiel form til sine drømme - digteren i ekstase foran en bestandigt blank side. [...] Det er romantisk at betragte konkret udtryk som en dekadence, en kontamination" ${ }^{26}$ Og måske endnu tydeligere hos Percy B. Shelley, der forestillede sig digteren som en nattergal, der synger for at opmuntre sig selv i sin ensomhed i Defence of Poetry (1821), hvor det hedder: "when composition begins, inspiration is already on the decline, and the most glorious poetry that has ever been communicated to the world is probably a feeble shadow of the original conception of the poet". ${ }^{27}$ Shelley udtrykker her en ekstrem neoplatonisk idealisme, som konsekvent nedtoner digtningens materielle form og udtryk, og som har medvirket kraftigt til, at romantikkritikken (fx i skikkelse af Harold Bloom) har været blind for dette aspekt.

Året efter luksusudgaven af Elegiac Sonnets udkom den digtsamling, som om nogen har defineret, hvad eftertiden forstår som romantisk digtning, Wordsworth og Coleridges Lyrical Ballads, uden frontispice-portræt, uden illustrationer og uden de ekstra dekorationer, Smith i et brev nærmest som en eftertanke giver udtryk for gerne at ville inkludere i Elegiac Sonnets i 1797:

(f as there are (from the structure of the verse) many considerable marginal vacancies, [...] I could wish trophies (which if it had been thought of sooner I could have drawn appropriate to the subjects myself) could be put to fill up such vacancies [...] perhaps you might obtain plates of them or the Printer may have such, \& Which, tho not so elegant as they might have been, will fill these awkard vacancies. If there was any possibility of getting them engraved [...] I cd send up drawings in a day's time. (Letters 272-3)

Selvom det ikke blev til noget med disse ekstra dekorationer, er ønsket om dem udtryk for Smiths dybe og vedholdende engagement i alle aspekter af sin bogs visuelle udtryk, og for hendes evner som grafiker (hun var trænet i tegning, som det var god etikette for overklassens unge piger).

Lyrical Ballads er i sammenligning med Elegiac Sonnets påfaldende ren og klar i sit udtryk; den er radikalt uornamenteret. Dette var ikke normen i 1790'erne, men fint udtryk for den nyskabende poetik, de to digtere arbejdede ud fra. I et brev, Wordsworth og Coleridge skrev i fælleskab til deres udgiver, siger de: "I meant to have written you an Essay on the Metaphysics of Typography; but I have not time.-Take a few hints without the abstruse reasons for them with which I mean to favour you-18 lines in a page, the lines closely printed, [...] equal ink; \& large margins. That is beauty-it may even under your immediate care mingle the sublime!" ${ }^{28}$ Begge digtere var bevidste om digtningens bibliografiske koder og opsatte på at anvende dem til at producere æstetiske effekter af det skønne og sublime. De vidste, som Jerome McGann udtrykker det i anden anledning, at "tekstens perceptuelle træk er lige så passende udtryksmidler som dens semantiske, syntaktiske og retoriske træk". ${ }^{29}$ De var med andre ord lige så bevidste omkring layout, som Smith var det, men de søgte en radikalt anderledes typografisk realisering af det poetiske materiale, som skulle danne norm for eftertidens opfattelse af romantisk typografi: 
Det er blevet et layout, man ikke bemærker, det er lige så transparent og ukunstlet, som de ønskede deres digte skulle fremstå. Der skulle ikke være nogle typografiske forsiringer, som kunne distrahere læseren og fjerne blikket fra digtet som udtryk for digterens sjæl. Den retoriske renselse, Lyrical Ballads er udtryk for, ønsket om at lutre det digteriske sprog for alle 'poetiske' klicheer og faste udtryk ("the gaudiness and inane phraseology of many modern writers"30) for at bringe det så tæt på det talte sprog som muligt, gennemføres med andre ord også på det typografiske plan. I en note til "The Thorn" understreger Wordsworth, at "Words, a poet's words more particularly, ought to be weighed in the balance of feeling, and not measured by the space which they occupy upon paper", ${ }^{31}$ mens Shelley forklarede Edward J. Trelawny, at han (på trods af sin neoplatoniske berøringsangst over for skrift og trykpresse) kun udgav sine digte for at undslippe sine egne fantasifostre:

When my brain gets heated with thought, it soon boils, and throws off images and words faster than I can skim them off. In the morning, when cooled down, out of the rude sketch [...] I shall attempt a drawing. If you ask me why I publish what few or none will care to read, it is that the spirits I have raised haunt me until they are sent to the devil of a printer. ${ }^{32}$

Shelleys motiv for at få sine digte på tryk er personligt snarere end økonomisk; det er en måde at undgå at blive hjemsøgt af sig selv ved så at sige at splitte sig fra sig selv i og med det trykte medie. Han antyder ikke, at det at trykke digtene bibringer dem nogen yderligere æstetisk værdi eller dimension.

For både Wordsworth og Shelley er digtningen - som den også var det for Smith - lig med digterens udtryk for sit indre følelsesliv. Men for de to herrer underordnes og underkendes digtningens materielle og fysiologiske aspekter, for så vidt de rækker ud over den talende og syngende stemmes rytmiske modulering af følelserne. Dette var ikke tilfældet for Smith, som i langt højere grad dels måtte operere på markedets betingelser og dermed skulle arbejde for at tiltrække sig læsernes opmærksomhed, dels var visuelt begavet og orienteret, og dermed langt fra den protestantiske og idealistiske billedskepsis, som dominerer det, man traditionelt har fremlæst af fx Lyrical Ballads og Shelleys Defence of Poetry og identificeret som den romantiske æstetik.

\section{II}

Lord Byron var på mange måder Smiths modstykke. Han skulle aldrig tjene på sin digtning (indtil sent i karrieren gav han sin udgiver, John Murray, fuld copyright), og han havde råd til at få taget adskillige portrætter samt få dem graveret til venner og elskerinder. Han autoriserede aldrig en udgivelse med sig selv på en frontispice, selvom hans portræt hurtigt blev udgivet i uautoriserede udgaver og florerede i den populære presse. ${ }^{33}$ Som nævnt kom Byron dog tæt på at autorisere et portræt i kølvandet på udgivelsen i marts 1812 af Childe Harold's Pilgrimage. Efter at være vågnet op for at opdage, at han var blevet berømt, blev Byron den mest efterspurgte og eftertragtede forfatter i England. Alle ville se ham og blive set med ham, og Byron 
deltog i den hype, som gjorde ham til et medieikon og medførte betegnelsen Byromania. Hertuginden af Devonshire sagde fx om Childe Harold, at den var "on every table, and himself courted, visited, flattered and praised whereever he appears [...] he is really the only topic of almost every conversation - the men jealous of him, the women of each other". ${ }^{34}$ Digtet solgte og var spændende, men digteren solgte endnu bedre og var langt mere interessant; som Walter Scott genkaldte sig nogle år efter: "a mighty and unexpected rival was advancing on the stage-a rival not in poetical powers only, but in the art of attracting popularity, in which the present writer had hitherto preceded better men than himself". ${ }^{35}$

Childe Harold var ikke illustreret, men snart var en tøvende digter og en ivrig udgiver i færd med at planlægge et frontispice-portræt, som skulle graveres efter en miniature af George Sanders og vedhæftes de mange optryk, der søgte at tilfredsstille læsernes hungren efter denne mystiske digter, man forestillede sig helten i digtet var et slet skjult portræt af. I september 1812 skrev Byron til Murray og spurgte: "when is the graven image [...] to grace, or disgrace, some of our tardy editions?" ${ }^{66}$ Byrons ambivalens over for projektet blev hurtigt til direkte modstand, da han i oktober gav udtryk for "a very strong objection to the engraving of the portrait, and request that it may, on no account, be prefixed [Childe Harold]; but let all the proofs be burnt, and the plate broken [...] I cannot permit the publication [...] for which I have reasons that I will state when I see you" (BLJ 2: 224-5). Vi har ikke disse begrundelser, men i et brev skrevet kort tid efter afslører Byron sin aversion mod at blive udgivet i dette format, da han siger, at den nu (med undtagelse af et enkelt tryk Murray fik lov til at gemme, se fig. 3) destruerede gravering "was unlike the picture; and besides, upon the whole, the frontispiece of an author's visage is but a paltry exhibition. At all events, this would have been no recommendation to the book" (BLJ 2: 234).

Ikke at udgive med et portræt, når alle andre enten gjorde det eller gerne ville gøre det, og læserne hungrede efter det, var Byrons måde at vise det, Jerome Christensen kalder hans 'strength', og dermed skille sig ud som sig selv. ${ }^{37}$ Frontispice-portrætter var tegn på dårlig smag og en vulgær interesse i markedsføring og kommercialisme; og hvad værre var, de var tegn på den egoisme og navlepillende interesse for digterens selv, han afskyede og forbandt med Wordsworth (Byron ville ikke nedværdige sig til at anerkende, at Smith stod bag Wordsworth). Som Byron skrev i sin dagbog i 1813: "To withdraw myself from myself (oh that cursed selfishness!) has ever been my sole, my entire, my sincere motive in scribbling at all; and publishing is also the continuance of the same object, by the action it affords to the mind, which else recoils upon itself" (BLJ 3: 225). Et frontispice-portræt ville reflektere selvet tilbage fra digtet på en alt for direkte måde, i det konkrete tilfælde understreget af, at Byron kigger os direkte i øjnene og ikke, som det var blevet normen, til siden i en slags selvoptagethed.

Byron modsatte sig endog at få sit navn på titelbladet til Childe Harold (BLJ 2: 75-6), og i 1811 sagde han: "I by no means intend to identify myself with Harold, but to deny all connexion with him. If in parts I may be thought to have drawn from myself, believe me it is but in parts, and I shall not own even to that [...] I would not be such a fellow as I have made my hero for the world" (BLJ 2: 121-22). I forordet til 
Fig. 3: Byron, frontispice-portræt ikke bragt i Childe Harold's Pilgrimage (London, 1812).

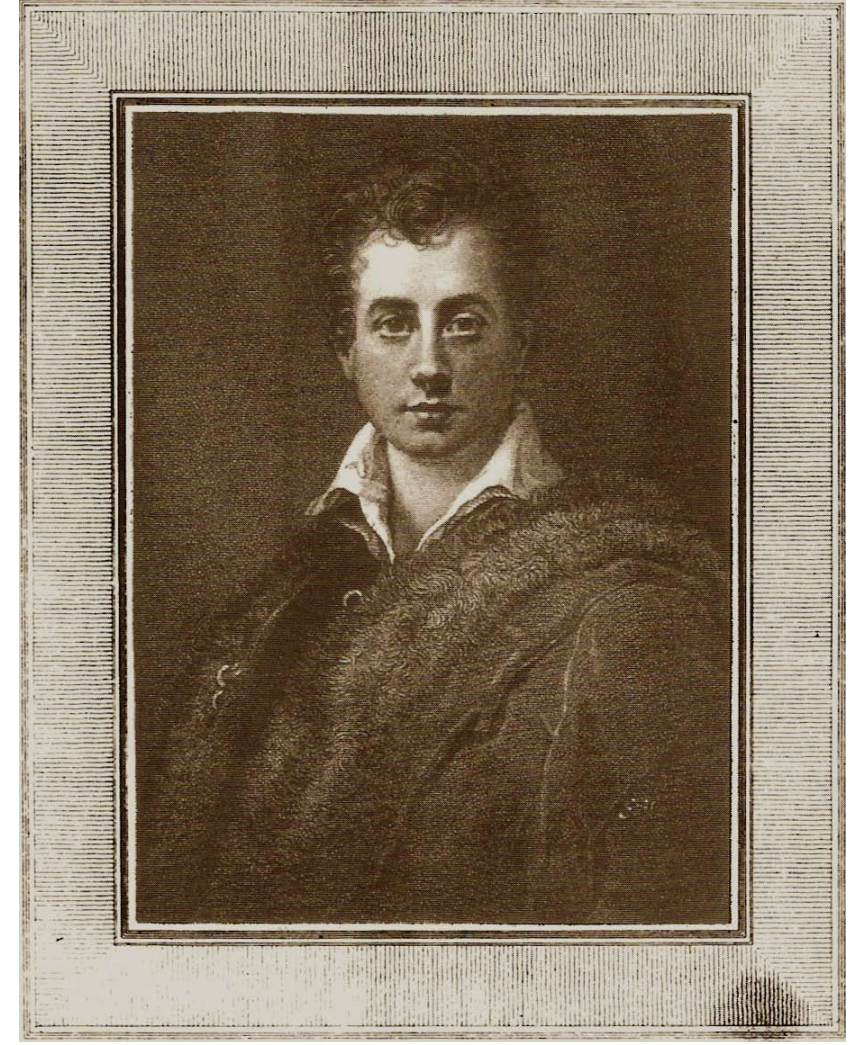

Childe Harold anerkender Byron, at visse dele af digtet er baseret på hans egne observationer fra en rejse på kontinentet, men han siger også, at Harold er "the child of imagination", og han opponerer mod "the suspicion of having intended some real personage".$^{38}$ Som Byron udmærket var klar over, holdt dette ikke nogen læsere tilbage fra at læse imod forfatterintentionen. Tværtimod, for at sige på dette tidspunkt - midt i romantikken, tyve år efter Charlotte Smith havde etableret konventionen, og et par år inden Coleridge tog den for givet i Biographia Literaria - at der ingen forbindelse var mellem digteren og helten i et digt, var at etablere denne forbindelse hinsides enhver tvivl. Men at gøre det på netop den ironiske og uoprigtigt oprigtige måde, som er blevet Byrons varemærke.

Fraværet af et portræt af digteren var en essentiel ingrediens i Byrons vigtigste frembringelser: Den Byronske Helt og Byromania. Begge disse fænomener er drevet af dobbeltheder, tvivl, tvetydigheder, det skjulte, hemmelige og kun antydelsesvist omtalte. Den Byronske Helt er sublim og ikke i stand til at blive fanget og fastholdt $i$ et enkelt billede. Han rummer altid usete dybder, som Conrad fra The Corsair (1814) er et godt eksempel på:

Sun-burnt his cheek, his forehead high and pale

The sable curls in wild profusion veil;

And oft perforce his rising lip reveals

The haughtier thought it curbs, but scarce conceals.

Though smooth his voice, and calm his general mien,

Still seems there something he would not have seen:

His features' deepening lines and varying hue

At times attracted, yet perplex'd the view,

As if within that murkiness of mind 
Work'd feelings fearful, and yet undefined;

Such might it be-that none could truly tell-

Too close inquiry his stern glance would quell..$^{39}$

At gengive denne mobile, kamæleonagtige helt i en visuel og fikseret form ville være at fjerne den magi og aura, der omkranser ham og indhyller ham i sit eget mysterium. På en måde skaber og bibeholder Byron en tilsvarende aura og magi omkring sig selv som digter ved ikke at bruge et frontispice-portræt, der ville fiksere ham i et enkelt billede. I fraværet af et portræt er det op til læseren at forestille sig digteren i billedet af helten. I dedikationen af The Corsair til Thomas Moore skriver Byron: "if I have deviated into the gloomy vanity of 'drawing from self', the pictures are probably like, since they are unfavourable”, og han fortsætter med at sige, at han forestiller sig Harold som "a very repulsive personage; and as to his identity, those who like it must give him whatever 'alias' they please". ${ }^{40}$ Byron vidste, at hans læsere $ø$ skede den direkte forbindelse mellem digter og digt, liv og værk, men i stedet tilbød han læseren endnu mere, nemlig chancen for at blive involveret i Byromania ved at spekulere på og deltage i etableringen af forbindelsen mellem digteren og digtet.

Fraværet af et autoriseret "graven image" som frontispice kan med andre ord ses som et aspekt af Byrons paradoksale måde at udtrykke sig selv på. I 1823 skal han have sagt:

People take for gospel all I say, and go away continually with false impressions [...] One will represent me as a sort of sublime misanthrope, with moments of kind feeling. This par example, is my favourite rôle. Another will portray me as a modern Don Juan; and a third [...] will [... ] represent me as an amiable, ill-used gentleman, 'more sinned against than sinning'. Now, if I know myself, I should say, that I have no character at all [...] But, joking apart, what I think of myself is, that I am so changeable, being every thing by turns and nothing long [...] that it would be difficult to describe me.4r

Byron så igennem den romantiske æstetik, som blev indvarslet af Smith, udfoldet af Wordsworth og teoretiseret af Coleridge (hvis væsentligste teoretiske arbejde var udformet som en selvbiografi); han vendte den på hovedet og brugte den på sin egen måde til på paradoksal vis at udtrykke sig selv som sig selv i sit 'værk' (forstået som noget der fx inkluderer det ikke bragte frontispice-portræt samt Byrons sociale maskespil). I 1822 fik den amerikanske maler, William Edward West, lov til efter lang tids plagen at tage et portræt af Byron i Italien, og han sagde efterfølgende, at digteren "assumed a countenance that did not belong to him, as though he were thinking of a frontispiece for "Childe Harold"'. ${ }^{42}$ At forstå Byron er at indse det absurde i forestillingen om, at noget ansigtsudtryk eller nogen mine ikke tilhører ham; med andre ord fejlagtigt at antage, at der neden under Byrons masker gemmer sig et stabilt, essentielt, autentisk og centralt selv, som man kan læse sig igennem til.

Både Elegiac Sonnets og Childe Harold's Pilgrimage er med andre ord udtryk for, at de engelske romantikere var yderst bevidste om det trykte medies ekspressive potentiale, og at de, for så vidt det kunne lade sig gøre, var rede til at manipulere med mediet for at fremme budskabet og iscenesætte digterens selv som digtets ma- 
teriale. Dette skulle ikke komme som nogen overraskelse, for som Walter Ong har påpeget, blev "typografi [...] definitivt internaliseret i den vesterlandske psyke på det tidspunkt i den vestlige historie, vi kender som den Romantiske Bevægelse". ${ }^{43}$ I løbet af romantikken blev det at være digter det samme som at være udgivet i trykt bogform, med eller uden det altafgørende frontispice-portræt, dvs. på vidt forskellig vis. Det har været denne artikels hovedærinde at påpege nogle grundlæggende forskelle i digteres brug af deres bogmedie for at kunne konkludere, at en vis åbenhed og positiv indstilling over for romantikernes (og alle andre forfatteres) brug af de materielle, visuelle og kropslige for- og bagsider af bogens forunderlige og foranderlige væsen kan lede til en bedre forståelse og en rigere oplevelse af deres værk.

\section{Noter}

I "What is poetry? is so nearly the same question with, what is a poet? that the answer to the one is involved in the solution to the other". Samuel Taylor Coleridge, Biographia Literaria 2 bd., red. Walter Jackson Bate \& James Engell (Princeton, 1983), bd. 2, 15-17. Denne og alle andre oversættelser fra engelsk i denne artikel er mine egne.

2 "A book without a portrait of the author, is worse than anonymous. As in a church-yard, you may look on any number of ribs and shin-bones, as so many sticks merely, without interest; but if there should chance to be a scull near hand, it claims the relics at once,- - so it is with the author's head-piece in front of his pages. The portrait claims the work". Thomas Hood, Whims and Oddities in Prose and Verse. A New Edition (London, 1836), 194.

3 Judith Phillips Stanton red., Collected Letters of Charlotte Smith (Bloomington, 2003), 104. Herefter forkortet Letters med henvisninger i parentes.

4 Se Judith Phillips Stanton, “Charlotte Smith's 'Literary Business': Income, Patronage, and Indigence", The Age of Johnson: A Scholarly Annual 1 (1987), 375-401, og Loraine Fletcher, Charlotte Smith: A Critical Biography (Basingstoke, 2001).

5 Se Cynthia J. Brown, Poets, Patrons, and Printers: Crisis of Authority in Late Medieval France (Ithaca \& London, 1995), 99-151. Om frontispice-portrættets historie, se desuden Kurt Weitzmann, Ancient Book Illumination (Cambridge MA, 1959), 116, David Bland, A History of Book Illustration: The Illuminated Manuscript and the Printed Books (London, 1958), 26, og David Piper, The Image of the Poet: British Poets and Their Portraits (Oxford, 1982). Om frontispice-portrættets funktion, se Steven Rendall, "The Portrait of the Author", French Forum 13:2 (1988), 143-151, Roger Chartier, The Order of Books: Readers, Authors, and Libraries in Europe Between the Fourteenth and Eighteenth Centuries (Cambridge, 1994), 25-59, Gerard Curtis, Visual Words: Art and the Material Book in Victorian England (Aldershot, 2002), 103-202, og Janine Barchas, Graphic Design, Print Culture, and the Eighteenth-Century Novel (Cambridge, 2003), 19-59.

6 Robert Southey, Letters from England, red. Jack Simmons (London, 1961), 117.

7 Citeret fra Leo Braudy, The Frenzy of Renown: Fame and Its History (New York, 1997), 436.

8 Ibid.

9 Letters 268. Om Mary Robinsons brug af sit portræt, se Eleanor Ty, "Engendering a Female Subject: Mary Robinson's (Re)Presentations of the Self', English Studies in Canada 21:4 (December 1995), 407-431.

Io Om Whitman, se Ed Folsom, "Appearing in Print: Illustrations of the Self in Leaves of Grass", i Cambridge Companion to Whitman, red. Ezra Greenspan (Cambridge, 1995), 135-55. Whitmans 
anmeldelse citeres af Folsom p. 137. Nicolas Barker hævder, at det var i anden halvdel af det attende århundrede, at frontispicen og titelbladet begyndte at blive brugt som æstetiske udtryksmidler og ikke blot som blikfang i handelsøjemed. Se hans "Typography and the Meaning of Words: The Revolution in the Layout of Books in the Eighteenth Century", i Buch und Buchhandel in Europa im achtzehnten Jahrhundert/The Book and the Book Trade in Eighteenth-Century Europe, red. Giles Barber \& Bernhard Fabian (Hamburg, 1977), 127-165.

II Citeret fra forordet til Charlotte Smith, The Poems, red. Stuart Curran (New York \& Oxford, 1993), xix.

I2 "By writing poetry of the Self, Smith produces, directs and enacts Romanticism". Jacqueline Labbe, Charlotte Smith: Romanticism, Poetry, and the Culture of Gender (Manchester, 2003), 172. Se tillige Sarah Zimmerman, “'Dost thou not know my voice?': Charlotte Smith and the Lyric's Audience", i Romanticism and Women Poets: Opening the Doors of Reception, red. Harriet Kramer Linkin \& Stephen Behrendt (Lexington, 1999), 101-124.

I3 Harold Bloom, The Visionary Company: A Reading of English Romantic Poetry (Ithaca \& London, 1971), 461.

I4 Harold Bloom \& Lionel Trilling red., The Oxford Anthology of English Literature 2 bd. (New York \& London, 1973), bd. 2, 125.

I5 Stuart Curran åbnede fx forordet til sin skelsættende udgave af hendes samlede digte fra 1993 med at sige, at "Charlotte Smith was the first poet in England whom in retrospect we would call Romantic". Smith, The Poems, xix.

I6 Harold Bloom, "The Visionary Cinema of Romantic Poetry”, i William Blake: Essays for S. Foster Damon, red. Alvin H. Rosenfeld (Providence, 1969), 20.

I7 Jf. Christopher Rovee, Imagining the Gallery: The Social Body of British Romanticism (Stanford, 2006), 109, og Fletcher, Charlotte Smith, 261.

I8 Citeret fra Judith Pascoe, Romantic Theatricality: Gender, Poetry, and Spectatorship (Ithaca, 1997), 17. Året før havde Gentleman's Magazine tilsvarende skrevet om tredje udgave af Elegiac Sonnets, at digtene "which are the genuine offspring of her own fancy, are by far the most interesting in her whole collection". Citeret fra Zimmerman, "Dost thou not know my voice”, 106.

I9 Bruce Graver har i forbindelse med Robert Bloomfields The Farmer's Boy vist, at dette langt hen ad vejen var gængs praksis på datidens bogmarked. Se Graver, "Illustrating The Farmer's Boy", Romanticism 9:2 (2003), 157-75.

20 Shipton er en reference til den legendariske engelske profet, der skulle være datter af Agatha Shipton og djævlen, og som efter sigende skrev Mother Shipton's Prophecies.

2I Smith, The Poems, 116, 11. 121-124.

22 Under portrættet i den endelige udgivelse blev der graveret en anden version af Shakespeares vers: "Oh! Time has Changed me since you saw me last, / And heavy Hours with Time's deforming Hand, / Have written strange Defeatures in my Face", mens Shakespeares original lyder: "O! grief hath chang'd me since you saw me last, / And careful hours with time's deformed hand / Have written strange defeatures in my face" (Comedy of Errors, V, I, 298-300). Det er ikke klart hvad eller hvem der er ansvarlig for ændringerne, men formodentlig er det Smith selv, der fremhæver tiden på sorgens bekostning og dermed nedtoner sin selvynk en smule.

23 Smith, Poems, 111n.

24 D. F. McKenzie, “Typography and Meaning: The Case of William Congreve”, i McKenzie, Making Meaning: 'Printers of the Mind' and Other Essays, red. Peter D. McDonald \& Michael F. Suarez (Amherst \& Boston, 2002), 201. 
Se Charles Taylor, Sources of the Self: The Making of the Modern Identity (Cambridge MA, 1989), 409.

26 Mario Praz, The Romantic Agony (Oxford \& New York, 1970), 14-15.

27 David Lee Clark red., Shelley's Prose: Or the Trumpet of a Prophecy (Albuquerque, 1966), 294.

28 Earl Leslie Griggs red., The Collected Letters of Samuel Taylor Coleridge 5 bd. (Oxford, 19561971), bd. 1, 412.

29 Jerome McGann, Radiant Textuality: Literature After the World Wide Web (Basingstoke \& New York, 2001), 183.

30 William Wordsworth \& Samuel Taylor Coleridge, Lyrical Ballads, red. R. L. Brett \& A. R. Jones (London, 1991), 7.

3I Ibid., 288.

32 Edward Dowden red., Trelawny's Recollections of the Last Days of Shelley and Byron (London, 1931), 49-50.

33 Om Byrons portrætter se Robert Beevers, The Byronic Image: The Poet Portrayed (Abingdon, 2005), Suzanne Hyman, "Contemporary Portraits of Byron", i Lord Byron and His Contemporaries, red. Charles E. Robinson (Newark NJ, 1982), og Christine Kenyon Jones, "Fantasy and Transfiguration: Byron and his Portraits", i Byromania: Portraits of the Artist in Nineteenth- and Twentieth-Century Culture, red. Frances Wilson (Basingstoke, 2000), 109-136.

34 Citeret fra Byromania, 4.

35 Citeret fra The Works of Lord Byron. Letters and Journals, red. Rowland E. Prothero (New York, 1966), 139n.

36 George Gordon Byron, Letters and Journals 12 bd., red. Leslie A. Marchand (London, 19731982), bd. 2, 191. Herefter forkortet $B L J$ med henvisninger i parentes.

37 Jerome Christensen, Lord Byron's Strength: Romantic Writing and Commercial Society (Baltimore \& London, 1993).

38 George Gordon Byron, Poetical Works, red. Frederick Page, rev. John Jump (Oxford \& New York, 1970), 179.

39 Ibid., 280-1.

40 Ibid., 277.

4 I Citeret fra Hyman, “Contemporary Portraits of Byron”, 204.

42 Citeret fra Byromania, 124.

43 Walter J. Ong, Interfaces of the Word: Studies in the Evolution and Consciousness of Culture (Ithaca, 1977), 283. 


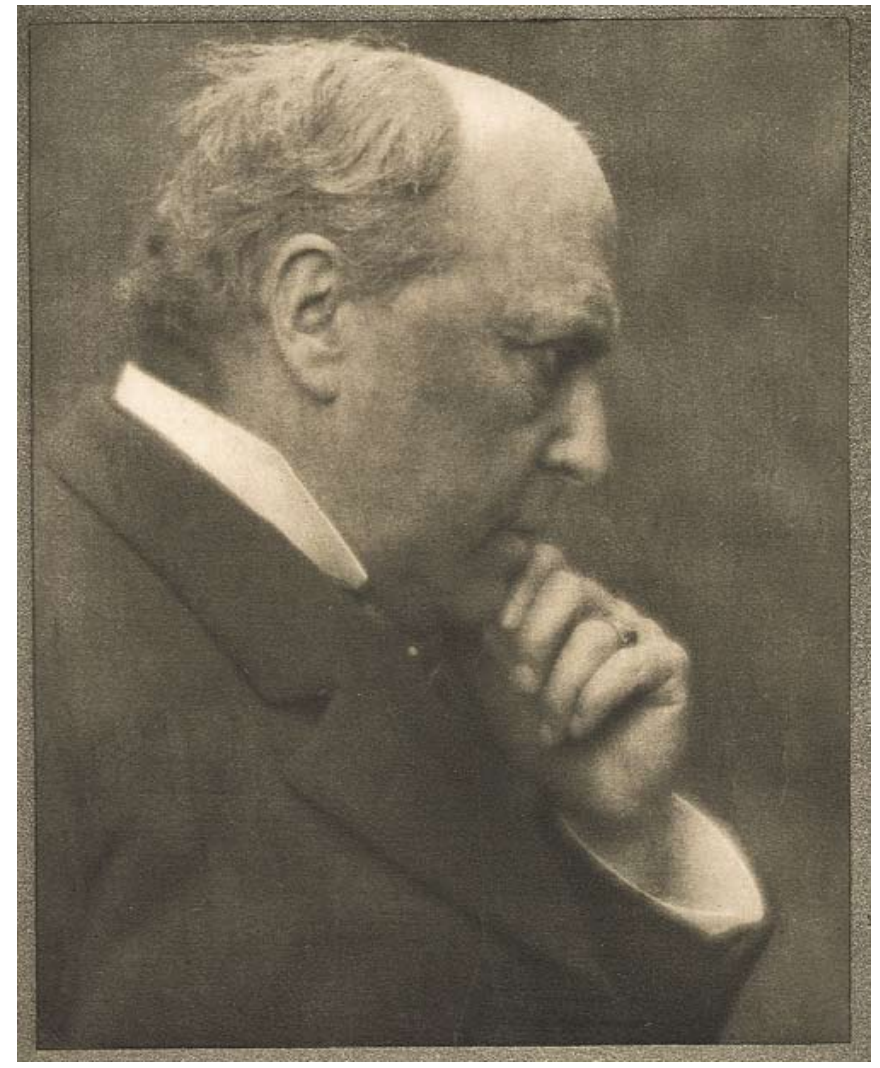

Henry James i eftertænksom profil 